Invited Review

\title{
Targeting DNA damage in SCLC
}

\author{
Victoria Foy $^{\mathrm{a}, 1}$, Maximilian W. Schenk ${ }^{\mathrm{a}, 1}$, Katie Baker ${ }^{\mathrm{a}, \mathrm{b}}$, Fabio Gomes ${ }^{\mathrm{c}, \mathrm{d}}$, Alice Lallo ${ }^{\mathrm{a}}$, \\ Kristopher K. Frese ${ }^{\mathrm{a}}$, Martin Forster ${ }^{\mathrm{e}}$, Caroline Dive ${ }^{\mathrm{a}, \mathrm{b}}$, Fiona Blackhall ${ }^{\mathrm{c}, \mathrm{f}, *}$ \\ a Clinical and Experimental Pharmacology Group, Cancer Research UK Manchester Institute, University of Manchester, UK \\ b Cancer Research UK Lung Cancer Centre of Excellence, UK \\ c Department of Medical Oncology, The Christie NHS Foundation Trust, Manchester, UK \\ d Oncologia Medica, Centro Hospitalar Lisboa Central, Lisboa, Portugal \\ e Department of Oncology, UCL Cancer Institute, University College London, London, UK \\ ${ }^{\mathrm{f}}$ Institute of Cancer Sciences, University of Manchester, Manchester, UK
}

\section{A R T I C L E I N F O}

\section{Keywords:}

Lung Cancer

Small Cell Lung Cancer

DNA Repair Pathways

PARP Inhibitors

Checkpoint Inhibitors

\begin{abstract}
A B S T R A C T
SCLC accounts for $15 \%$ of lung cancer worldwide. Characterised by early dissemination and rapid development of chemo-resistant disease, less than $5 \%$ of patients survive 5 years. Despite 3 decades of clinical trials there has been no change to the standard platinum and etoposide regimen for first line treatment developed in the 1970's.

The exceptionally high number of genomic aberrations observed in SCLC combined with the characteristic rapid cellular proliferation results in accumulation of DNA damage and genomic instability. To flourish in this precarious genomic context, SCLC cells are reliant on functional DNA damage repair pathways and cell cycle checkpoints.

Current cytotoxic drugs and radiotherapy treatments for SCLC have long been known to act by induction of DNA damage and the response of cancer cells to such damage determines treatment efficacy. Recent years have witnessed improved understanding of strategies to exploit DNA damage and repair mechanisms in order to increase treatment efficacy.

This review will summarise the rationale to target DNA damage response in SCLC, the progress made in evaluating novel DDR inhibitors and highlight various ongoing challenges for their clinical development in this disease.
\end{abstract}

\section{Introduction}

The incidence of lung cancer continues to rise, with small cell lung cancer (SCLC) currently accounting for $\sim 15 \%$ of cases. The highest incidence is in Central and Eastern Europe [1] reflecting the direct link between SCLC and cigarette smoking [2]. Biologically, SCLC is characterised by a rapid cancer cell doubling time and early metastatic dissemination; two thirds of patients present with metastatic (extensive) disease (ED) [3]. Drug treatment has changed little in the past 30 years and very few patients survive beyond 5 years [4]. A platinum drug and etoposide (PE), with or without the addition of thoracic and prophylactic cranial radiation, is the universal frontline standard of care [4]. The aggressive nature of the disease leads to extremely rapid deterioration and median survival of only 3-4 months without chemotherapy [5] yet long term survival and cure can occasionally be achieved in patients with limited stage disease (LD) [6]. In patients with ED treatment is palliative with typical response rates of approximately $70 \%$, median progression free survival (PFS) and overall survival (OS) of approximately 6 and 9 months, respectively and 1 year survival rate of approximately $30 \%$ [7]. Unfortunately SCLC recurs in the vast majority of patients. The only drug approved by the United States Food and Drug Administration for treatment of relapsed SCLC in the second line setting is topotecan [5] for which response rates are low between 7 and 24\%, progression free survival approximately 3-4 months and overall survival approximately 6-8 months [8]. Agents such as irinotecan, temozolomide (TMZ), amrubicin and anthracycline based regimens have also shown similar activity to topotecan in the second line setting $[9,10]$.

SCLC is hallmarked by rapid development of acquired chemoresistance despite initial chemo and radiosensitivity (Fig. 1), with recurrence after initial therapy almost inevitable, usually within one year of treatment. Around $30 \%$ of patients have primary chemoresistant or refractory tumours and the probability of response to second-line chemotherapy can be predicted according to response to first-line

\footnotetext{
* Corresponding author at: Department of Medical Oncology, The Christie NHS Foundation Trust, Manchester, UK.

E-mail address: Fiona.blackhall@christie.nhs.uk (F. Blackhall).

${ }^{1}$ Contributed equally to this article.
} 


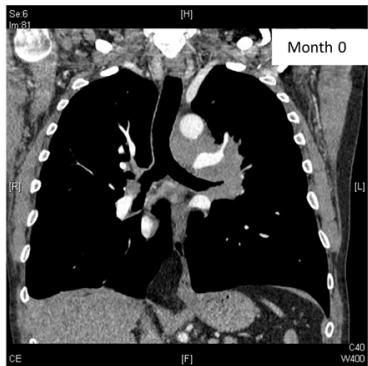

Baseline- Left hilar mediastinal disease

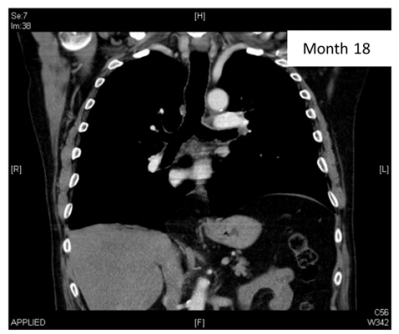

Post 4 cycles P/E chemotherapy rechallenge. Partial response

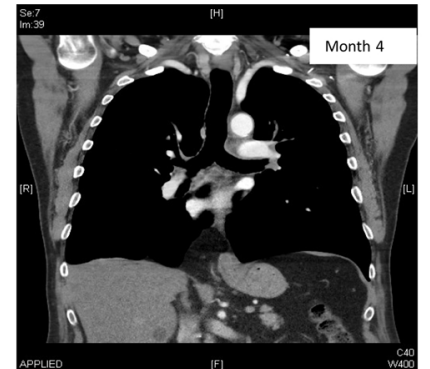

4 cycles of $\mathrm{P} / \mathrm{E}$ chemotherapy. Partial response

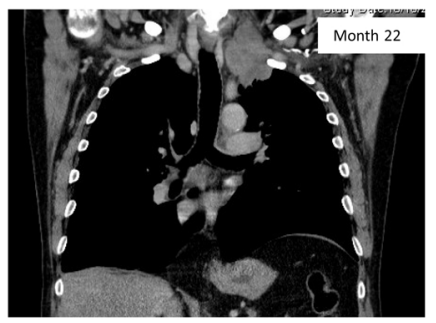

Progressive diseasehigh mediastinal/ supraclavicular region

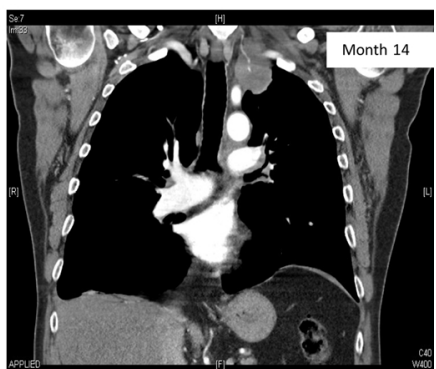

Fig. 1. CT images of disease during treatment for SCLC. treatment and the time to progression after completing it [11-14]. Patients with SCLC that relapse during first line platinum combination therapy or who have a treatment free interval of 60-90 days or less after the end of first-line therapy (resistant/refractory disease) have a worse outcome compared to those relapsing more than 90 days after completion of first-line therapy (sensitive disease) $[11,13,15]$. Due to the increasing tumour resistance to second line treatment and often rapid clinical deterioration during or following second line treatment, very few patients receive a third line of therapy. For these reasons earlier study enrolment into trials of maintenance or first line combination studies have become more common.

Current cytotoxic drugs and radiotherapy treatments for SCLC have long been known to act by induction of DNA damage and the response of cancer cells to such damage determines treatment efficacy [16]. Recent years have witnessed improved understanding of strategies to exploit DNA damage and repair (DDR) mechanisms in order to enhance sensitivity and/or overcome resistance to conventional DNA damaging treatments [2]. The DDR network is highly complex and dynamic with at least 450 proteins integral to DNA repair [17]. Different DDR proteins and pathways have the ability to compensate in the absence of integrity of the optimal pathway [16]. Five major DNA repair pathways are known: base excision repair (BER) to repair single-strand breaks (SSBs); homologous recombination repair (HRR) and non-homologous end-joining (NHEJ) to repair double-strand breaks (DSBs); mismatch repair (MMR) to repair replication errors, and nucleotide excision repair (NER) to repair bulky adducts caused by platinum salts and UV radiation, for example [16]. An armamentarium of novel DDR inhibitors, designed to inhibit distinct proteins critical for the integrity of these pathways are in various stages of preclinical and clinical development (see [16] for comprehensive review). Here we focus on the rationale to target DDR in SCLC, the progress made in evaluating novel DDR inhibitors and highlight various ongoing challenges for their clinical development in this disease.

\section{Rationale to evaluate DDR inhibitors in SCLC}

In the setting of tobacco-related carcinogenesis the SCLC genome is highly damaged as evidenced by an exceptionally high mutation
Progressive disease- high mediastinal disease left

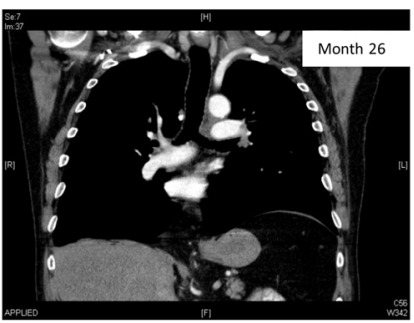

Post 4 cycles Topotecan. Partial response burden, with approximately 8.88 mutations per megabyte $[3,18]$. The tumour suppressor genes TP53 and RB1 are the most commonly mutated, with TP53 virtually universally mutated in SCLC. The oncogenic transcription factors MYC and SOX2 are amplified in $27 \%$ of cases, and histone modifiers such as CREBBP1 and EP300 are mutated in 15\% and $13 \%$ of cases, respectively [3,19-21] (Table 1 ). The majority of mutations have little significance for the SCLC pathogenesis and are described as passenger mutations. The challenge is to find driver mutations in a heterogeneous disease between patients and then being able to use them as actionable targets for treatments. Performing whole genome sequencing to identify therapeutically targetable oncogenic driver mutations, George et al. detected BRAF, KIT, and PIK3CA mutations in 4 out of 110 tumours analysed [3,19-21]. Although discrete, druggable subsets akin to those observed for non-small cell lung cancer (NSCLC) have not been identified, these results indicate that some patients might benefit from genotyping and subsequent targeted therapy [3,19-21]. The net consequence of the genomic aberrations in SCLC is rapid cellular proliferation in the context of accumulating DNA damage due to replication stress [22] and genomic instability. Replicative stress is the accumulation of errors during endogenous DNA replication. DNA repair pathways can maintain genomic integrity in times of replicative stress but defects in regulators, checkpoints or DNA repair pathways can result in genomic instability [23]. For instance, aberrant activation of the oncogene MYC in an RB1 and TP53 mutant background results in rapid proliferation and ultimately replication stress in SCLC [2]. To flourish in this precarious genomic context, SCLC cells are reliant on functional DDR pathways and cell cycle checkpoints. However, defects in the DDR mechanisms can be present and be compatible with tumour survival. These aberrations create potential 'Achilles heels' and opportunities to selectively increase the therapeutic effect of DNA-damaging agents on cancer cells by inhibition of the remaining intact DDR. Aberrations in DDR proteins or pathways have also been implicated in resistance to conventional DNA damaging agents [24].

Although little is known about the molecular mechanisms in SCLC that confer resistance to chemotherapy, three main mechanisms of platinum resistance have been described. The first two concern drug handling; reduced intracellular drug accumulation and increased inactivation of the drug, the third concerns increased capability for repair 
Table 1

Genomic alterations in SCLC, percentages based on George et al.

\begin{tabular}{|c|c|c|c|c|}
\hline Gene & Alteration & Pathway involved in & Consequence & Reference \\
\hline TP53 (98\%) & Inactivation & Cell Cycle Regulation & G1/S transition, proliferation, cell survival & {$[3,19,21]$} \\
\hline RB1 (91\%) & Inactivation & Cell Cycle Regulation & G1/S transition, proliferation, cell survival & {$[3,19,21]$} \\
\hline RBL1 (6\%) & Inactivation & Cell Cycle Regulation & G1/S transition, proliferation, cell survival & [3] \\
\hline RBL2 (6\%) & Inactivation & Cell Cycle Regulation & G1/S transition, proliferation, cell survival & [3] \\
\hline TP73 (13\%) & Activation & Cell Cycle Regulation & $\mathrm{G} 1 / \mathrm{S}$ transition, proliferation, cell survival & [3] \\
\hline CDKN2A (5\%) & Inactivation & Cell Cycle Regulation & G1/S transition, proliferation, cell survival & [3] \\
\hline KIT $(6 \%)$ & Activation & Receptor kinase/PI3K signalling & Proliferation, cell survival, translation & [3] \\
\hline FGFR1 (6\%) & Activation & Receptor kinase/PI3K signalling & Proliferation, cell survival, translation & [3] \\
\hline PTEN $(9 \%)$ & Inactivation & Receptor kinase/PI3K signalling & Proliferation, cell survival, translation & [3] \\
\hline EP300 (13\%) & Inactivation & Transcriptional Regulation & Chromatin modifications & {$[3,19,21]$} \\
\hline CREBBP (15\%) & Inactivation & Transcriptional Regulation & Chromatin modifications & {$[3,19,21]$} \\
\hline MYCL1 (9\%) & Activation & Transcriptional Regulation & Cell cycle progression, cell growth & [3] \\
\hline MYCN (4\%) & Activation & Transcriptional Regulation & Cell cycle progression, cell growth & [3] \\
\hline MYC (6\%) & Activation & Transcriptional Regulation & Cell cycle progression, cell growth & [3] \\
\hline NOTCH familiy genes $(25 \%)$ & Inactivation & Notch signalling/neuroendocrine differentiation & Neuroendocrine markers & [3] \\
\hline SOX2 $(27 \%)$ & Amplification & Maintenance of pluripotency of stem cells & SCLC proliferation & [19] \\
\hline
\end{tabular}

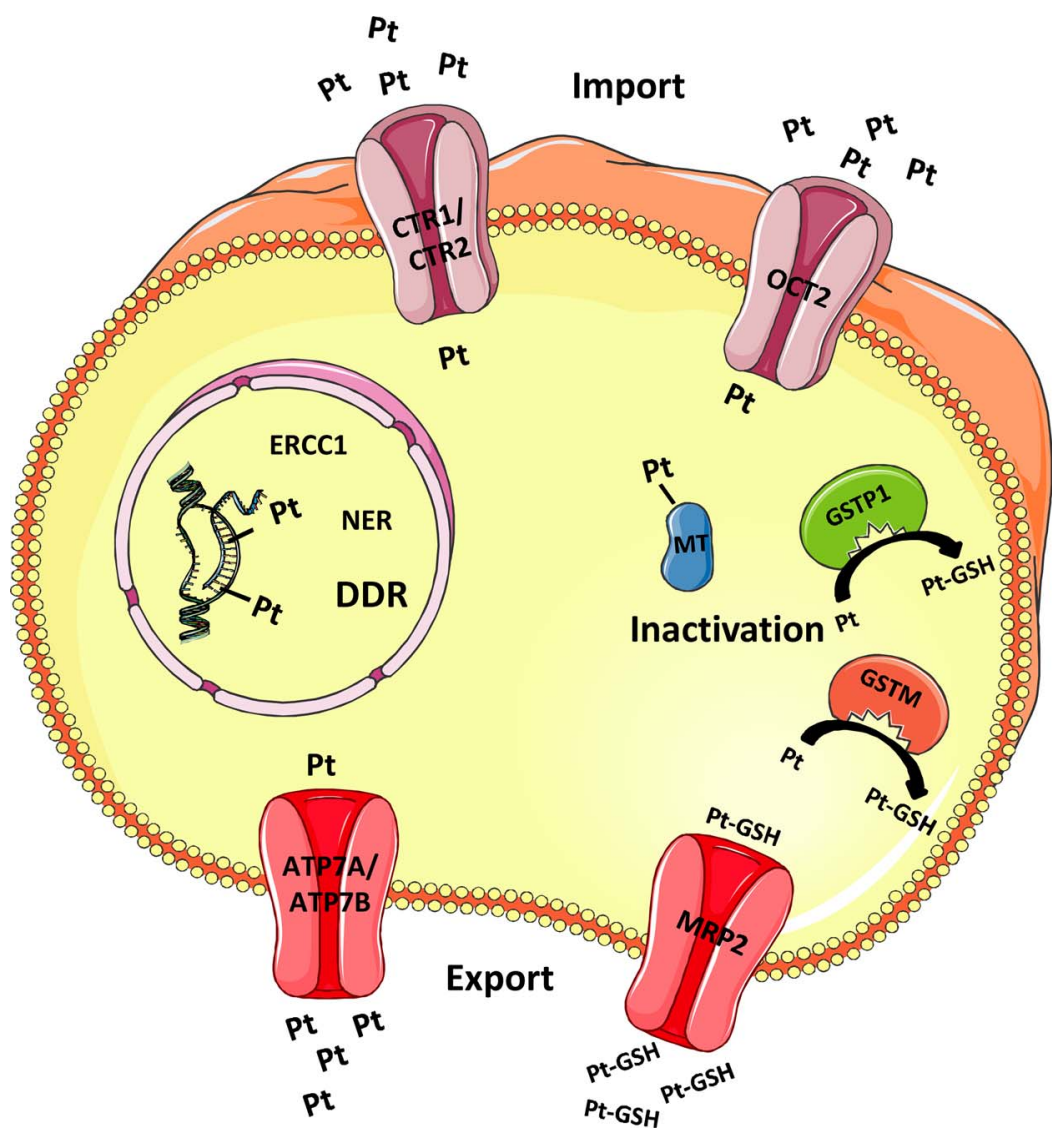

Fig. 2. Cellular fate of Cisplatin.

of DNA damage [25] (Fig. 2). Platinum compounds damage DNA by causing DNA replication barriers from the intercalation of platinum adducts into DNA [26]. Upon uptake into cells, cisplatin is hydrolysed in the cytoplasm and the chloride atoms are displaced by water molecules [26]. Consequently, cisplatin acts as an electrophile that can react with nitrogen on nucleic acids and sulfhydryl groups on proteins [26]. In the majority of cases, cisplatin causes 1,2-intrastrand cross-links of purine bases and thereby hinders cell division, causing DNA damage and leading ultimately to apoptosis [26,27]. DNA damage seems to contribute most to cisplatin toxicity, which is underlined by the fact that cells with deficient DNA repair are hypersensitive to cisplatin [28]. The bulky adducts generated by cisplatin are repaired by nucleotide excision repair (NER) pathway [29] and cell death depends on the balance of DNA damage and repair [30].
In clinical studies of patients with SCLC a low expression level of excision repair cross complementation group 1 (ERCC1), a endonuclease part of the NER, correlates with clinical outcome. Low ERCC1 expression in tumours is associated with a higher response rate and longer survival of SCLC patients with limited disease (LD) [31,32]. With respect to mechanisms of resistance to other cytotoxics, etoposide and topotecan inhibit the topoisomerase enzymes II and I respectively, culminating in DNA DSBs. Studies by Dingemans et al. and Karachaliou et al. demonstrate a correlation between the survival of SCLC patients and the expression of DNA Topoisomerase I and II [32,33]. High expression of TOPI, TOPIIA, and TOPIIB is associated with a shorter PFS in LD patients, whereas high expression of TOPIIB is associated with low response rates [32,33]. Although circumstantial, these findings implicate a role for DDR mechanisms in chemoresistance. 
A further rationale to target DDR mechanisms comes from knowledge that cancer cells often harbour defects and/or dysregulation of DDR proteins and pathways $[34,35]$. While there is a paucity of data specific to SCLC, Byers et al. [36] conducted an elegant study that identified the DNA repair protein, poly (ADP-ribose) polymerase 1 (PARP 1) as a therapeutic target. A total of 34 SCLC cell lines were profiled for the expression of 193 total and phosphoproteins. PARP1 was found to be highly expressed at both the mRNA and protein levels. Preclinical SCLC models were sensitive to PARP inhibition alone and the efficacy of chemotherapy was also enhanced by the addition of a PARP inhibitor [36]. Interestingly, SCLC cell lines revealed comparable or higher chemosensitivity than two breast cancer cell lines with BRCA1 or PTEN mutations, and PARP inhibitor sensitivity correlated with PARP levels [36]. Clinical studies testing several PARP inhibitors are currently ongoing and are discussed below.

Simplistically, DDR inhibitors may have efficacy in patients with SCLC in two ways:

a) A DDR inhibitor may be synergistic when combined with a conventional cytotoxic(s) through prevention of usual repair/treatment resistance.

b) Or, a DDR inhibitor may have monotherapy activity in a genomic context that causes vulnerability in one or more DDR pathways. This is the concept of so-called 'synthetic lethality' for which the paradigm is the well evidenced efficacy of PARP inhibition in cells with defective homologous recombination repair of DNA DSBs due to BRCA1 or BRCA2 deficiency [37].

\section{PARP inhibitors}

The family of PARP enzymes are highly abundant nuclear proteins that mediate BER and HRR, and alternative end joining (a-EJ). PARP1 is crucial for the repair of SSBs and is activated by stalled replication forks. PARP1 mediates the attachment of ADP-ribose units to multiple proteins to restart replication forks after DNA damage repair [2]. First, PARP1 inhibitors mediate their cytotoxic effect by trapping the enzyme to the SSB by preventing the utilization of $\mathrm{NAD}^{+}$[38]. Second, PARP1 inhibitors inhibit PARylation and therefore binding of PARP to DNA [38]. The resulting PARP-DNA complexes lead to collapsing and stalling of replication forks and ultimately to the conversion of SSBs to DSBs leading to apoptosis [38]. The development of PARP inhibitors (PARPi) has been largely driven by the concept of synthetic lethality, in which a combination of two deficiencies (in DDR) results in cell death but cells with only one deficiency present remain viable. PARP inhibition is 1000 times more potent in In BRCA-deficient cells in comparison to BRCA wild-type cells $[37,39]$. Olaparib is the most extensively investigated PARPi and is approved by the US FDA for use in pretreated advanced germline BRCA mutated ovarian cancer [40]. As already indicated, SCLC exhibits high levels of PARP1 expression and there are preclinical data to support PARP1 inhibition for clinical evaluation as a monotherapy and in combination with DNA damaging agents $[36,41,42]$. In tumour models PARP inhibitors synergise with agents that increase the prevalence of SSBs such as temozolomide $[43,44]$. In addition, in preclinical SCLC xenografts Byers et al. demonstrated single agent activity of olaparib, which was further increased when combined with cisplatin and etoposide or irinotecan [45]. The precise mechanism of action of PARP inhibition in SCLC is not well understood. However, non-HRR dependent mechanisms of PARP inhibitor sensitivity have recently been recognised and to date candidate biomarkers for PARPi sensitivity in SCLC identified have included a 17 DNA repair protein score [42] and SLFN11 expression [44]. Several PARP inhibitors have now entered clinical testing in patients with SCLC.

\subsection{Olaparib}

In the first line setting single agent olaparib was tested as maintenance treatment in a randomised, placebo-controlled phase II, 3 arm study conducted in the United Kingdom [46]. Patients were allocated to one of two doses of olaparib (300 mg twice daily (bd) or $200 \mathrm{mg}$ three times daily (tds)) or placebo. Eligible patients had pathologically confirmed LD/ED-SCLC with response to first line chemotherapy or chemo-radiotherapy. Patients were stratified by metastasis-status and prior radiotherapy. In 220 patients randomised to placebo, olaparib bd or oleparib tds the median PFS was $2.6(90 \% \mathrm{CI}$ 1.8, 3.7), 3.6 (90\% CI 3.1, 6.0) and 3.6 (90\%CI 3.1, 4.7) months and the median OS was 8.9 (90\% CI 7.0, 11.9), 9.9 (90\% CI 7.6, 12.9) and 9.0 (90\% CI 6.6, 11.8) months respectively. There was no significant difference in PFS or OS between olaparib and placebo for either the bd or the tds arm. There were more treatment discontinuations for olaparib (26 in olaparib BD, 25 olaparib TDS, 17 placebo group) and the most common toxicities were fatigue, nausea, anaemia, vomiting and anorexia.

In the setting of SCLC after platinum based chemotherapy (platinum sensitive and resistant disease), an objective response rate (ORR) of $46 \%$ was observed in a phase $1 / 2$ study of olaparib in combination with temozolomide. An expansion to 20 patients at the recommended phase 2 dose (RP2D) is now underway [47]. In an attempt to identify predictive biomarkers, this is an innovatively designed study with inclusion of baseline and serial tumour biopsies and blood samples to establish patient derived and circulating tumour derived xenograft/ explant models [48-50]. Various other trials of olaparib are ongoing (see Table 2) including strategies to combine olaparib with other DDR inhibitors rather than conventional cytotoxics (discussed later) and as 2nd or 3rd line monotherapy in a biomarker selected population with relapsed SCLC harbouring somatic BRCA 1/2 mutations, ATM deficiency or MRE11A mutations (NCT03009682). The latter study will be particularly interesting with respect to the frequencies of these genomic aberrations in a trial eligible population of patients.

\subsection{Veliparib}

Veliparib is a potent PARP $1 / 2$ inhibitor that was evaluated in combination with cisplatin and etoposide in a small phase I trial in the first line setting if ED-SCLC. This demonstrated the ability to safely deliver the combination of veliparib for 7 days of the 21 day cycle and resulted in an ORR of $71 \%$ (5/7 patients, 1 complete response (CR)). Although comparable to historical responses from chemotherapy alone the result proved that a PARP inhibitor could be tolerated in combination with chemotherapy [51]. The subsequent ECOG-ACRIN 2511 study (NCT01642251) of veliparib added to cisplatin and etoposide versus chemotherapy alone in the same 1st line setting was recently reported in abstract form [52]. A total of 128 patients with ED SCLC were randomised to receive a maximum of 4 cycles of cisplatin and etoposide with veliparib $100 \mathrm{mg}$ twice daily on days $1-7$ or matching placebo. The ORR had a mild and not statistically significant increase from $65.6 \%$ to $71.9 \%$ with the addition of veliparib ( $p=0.57$ ). The median PFS was 6.1 months for patients receiving veliparib which was statistically significantly better than for patients receiving placebo (PFS 5.5 months, HR $0.63, \mathrm{p}=0.01$ ). The median OS was 10.3 months for patients on veliparib and 8.9 months for patients on placebo which was not statistically significant $(\mathrm{HR}=0.83, \mathrm{p}=0.17)$. The veliparib and chemotherapy combination was less well tolerated with increased haematological toxicity, including neutropenia (9/9), leucopenia (9/9) and anaemia (8/9). Although statistically significant the 0.6 month difference in median PFS had questionable meaningful clinical benefit and highlights the unmet need for predictive biomarkers to select and enrich for patients most likely to benefit. The results from a randomised study of veliparib or placebo in combination with temozolomide as a second or third line therapy in patients with relapsed platinum sensitive or refractory SCLC have also been reported [53]. The ORR was significantly better for the combination (39\%) compared with that for temozolomide and placebo $(14 \%, \mathrm{p}$ value $=0.016)$. Disappointingly 


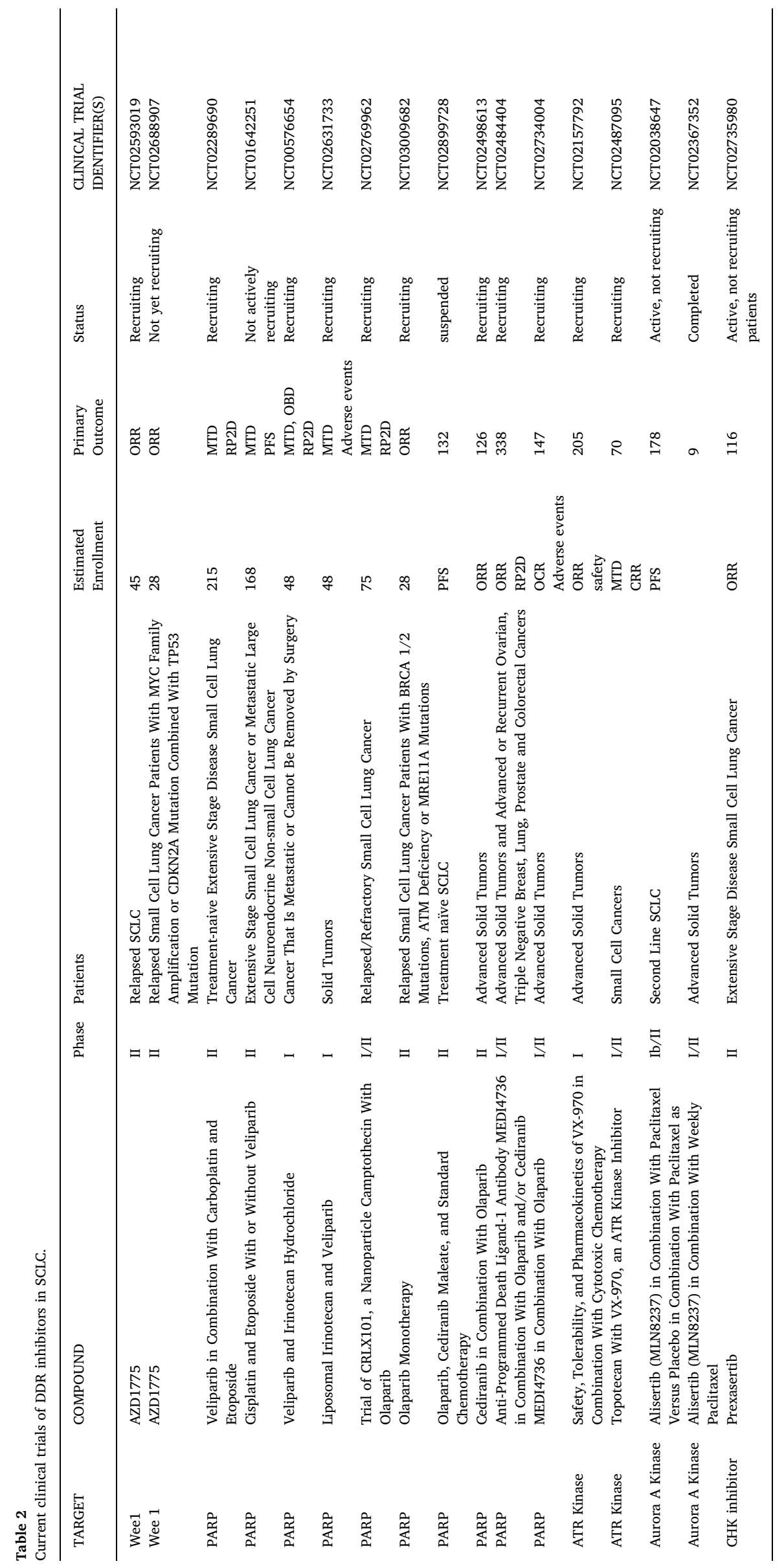

16

Downloaded for Anonymous User (n/a) at Centro Hospitalar Lisboa Central from ClinicalKey.com by Elsevier on November $29,2017$. For personal use only. No other uses without permission. Copyright $\odot 2017$. Elsevier Inc. All rights reserved. 


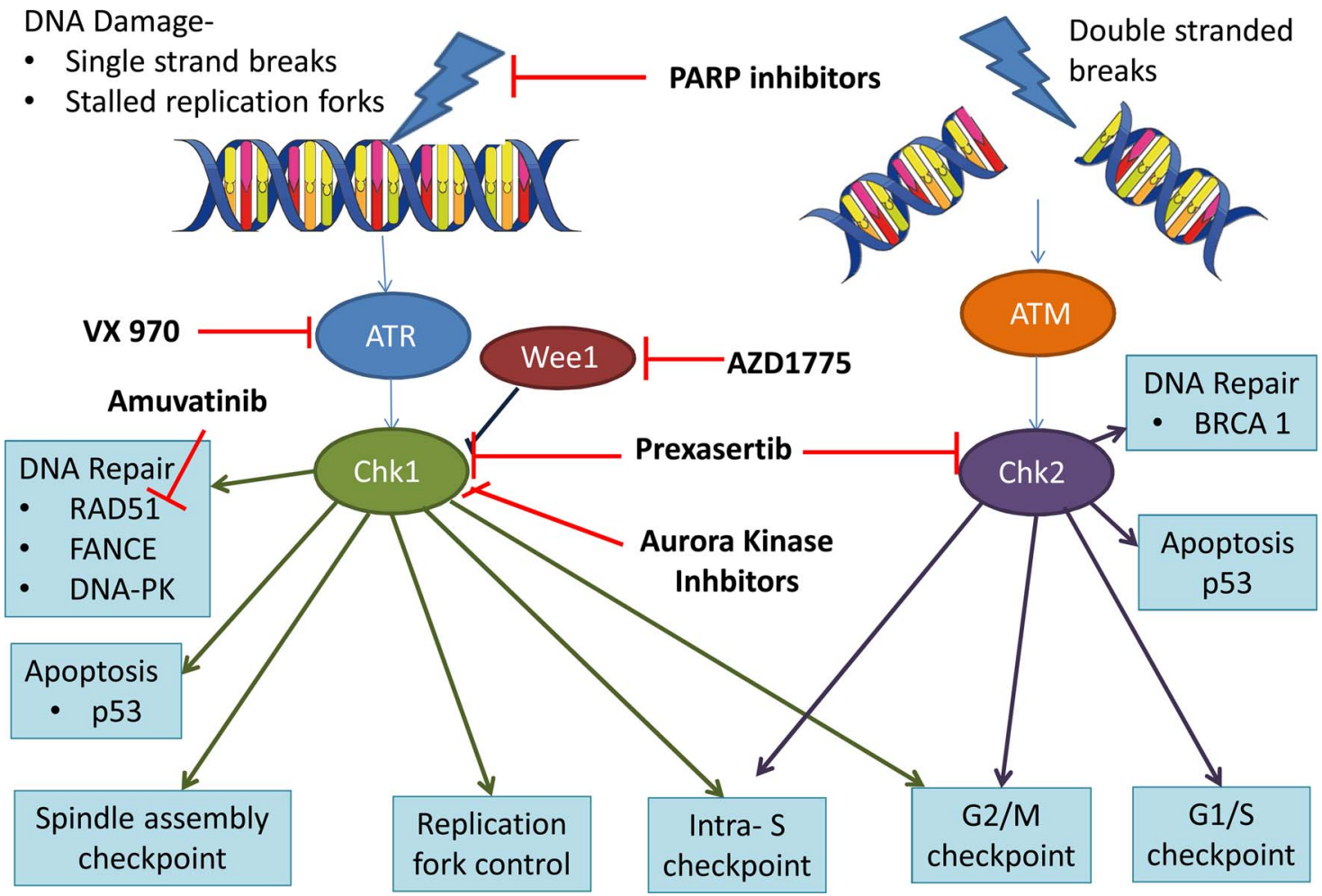

Fig. 3. DNA damage and therapeutics.

the 4 month PFS, median PFS and OS did not differ between the arms. Also, haematological toxicity was greater for the combination (Grades 3 and 4 thrombocytopaenia $50 \%$ in the combination arm vs $9 \%$ in TMZ arm, G3/4 neutropaenia $31 \%$ vrs $7 \%$ respectively. In this study tissue samples from approximately half of the patients enrolled were available for immunohistochemical (IHC) analysis of PARP1 and SLFN11 expression. There was no correlation between either biomarker with response although a trend to high SLFN11 expression and better overall survival was observed. SLFN11 is actively recruited to sites of DNA damage, inhibiting HR respectively) [54] and activating a cellular replication-stress response [55,56]. SLFN11 suppression has been associated with chemoresistance in SCLC models [57] and identified as a biomarker of PARP inhibitor response in SCLC PDX [44]. Circulating tumour cell enumeration was undertaken at baseline and after 1 cycle of chemotherapy. A count of $<5$ CTCs at baseline and after one cycle was observed to be prognostic for better outcome, independent of treatment received.

\subsection{Talazoparib}

Talazoparib is a novel and potent PARP inhibitor with a dual effect on PARP catalytic activity and PARP trapping [58]. In a phase 1 study of 100 patients with advanced solid tumours with DNA repair pathway defects, responses were observed in patients with BRCA mutated breast cancer, ovarian cancer and patients with SCLC. In a subsequent expansion cohort a clinical benefit rate (partial response (PR) + stable disease (SD) $>6$ weeks) of $26 \%(6 / 23)$ was demonstrated for talazoparib monotherapy among patients with platinum sensitive ED SCLC. Talazoparib was well tolerated with $4 \%$ grade III-IV toxicities, most commonly haematological suppression [59].

\section{Mitotic inhibitors (aurora kinase and checkpoint inhibitors)}

Aurora kinases play an important role in cell proliferation, controlling chromatin segregation, dispensing genetic material to the new cell during mitosis. Aurora kinase A promote mitosis through activation of CHK1 and aurora kinase B is functionally important in cytokinesis [60].

CHK1 prevents entry into mitosis by activating the $\mathrm{S}$ and $\mathrm{G} 2 / \mathrm{M}$ checkpoint and is involved in the co-ordination of HRR $[61,62]$.

The tyrosine kinase Wee1 negatively regulates entry into mitosis, arresting the cell at G2/M to enable DNA repair. Inhibition of Wee1 prevents G2/M arrest with the consequence that unchecked cells enter mitosis resulting in cell death through mitotic catastrophe or apoptosis [63-68].

\subsection{Alisertib}

Alisertib is an investigational selective aurora kinase A inhibitor, that has demonstrated single-agent anti-tumour activity in preclinical SCLC models and synergistic activity with paclitaxel in this setting [69]. In a phase I/II trial of Alisertib in refractory solid tumours, alisertib demonstrated single agent activity with an ORR of $21 \%(n=48)$ in the relapsed SCLC subgroups of patients, considerably higher than the $4 \%$ ORR observed in patients with NSCLC. Responses were observed in both platinum sensitive $(7 / 10)$ and platinum refractory disease $(3 / 10)$ with an overall PFS of 2.1 months [70]. However $43 \%$ of patients had serious drug-related adverse events.

The results of a randomised phase II study of paclitaxel $+/-$ alisertib in relapsed SCLC (NCT02038647) [69] were recently presented. Patients with relapsed SCLC $<180$ days after standard first-line platinum-based chemotherapy were randomised $1: 1$ to alisertib $40 \mathrm{mg}$ orally twice-daily on days $1-3,8-10,15-17+$ paclitaxel $60 \mathrm{mg} / \mathrm{m} 2 \mathrm{IV}$ on days 1, 8, 15 (Arm A) or matched placebo + paclitaxel $80 \mathrm{mg} / \mathrm{m} 2$ (Arm B) in 28-day cycles. Patients were stratified by type of relapse following frontline platinum (sensitive vs resistant/refractory) and presence/absence of brain metastases at baseline. In 178 patients randomised the primary endpoint of PFS was reached with a PFS of 101 days (3.32 months) for alisertib and paclitaxel versus 66 days (2.17 months) [HR $=0.71, \mathrm{p}=0.038]$ for placebo and paclitaxel and ORRs of $22 \%$, and $18 \%$, respectively. However, there was no significant difference in OS (6.1 vs 5.4 months, $\mathrm{p}=0.2$ ) in the overall population. 


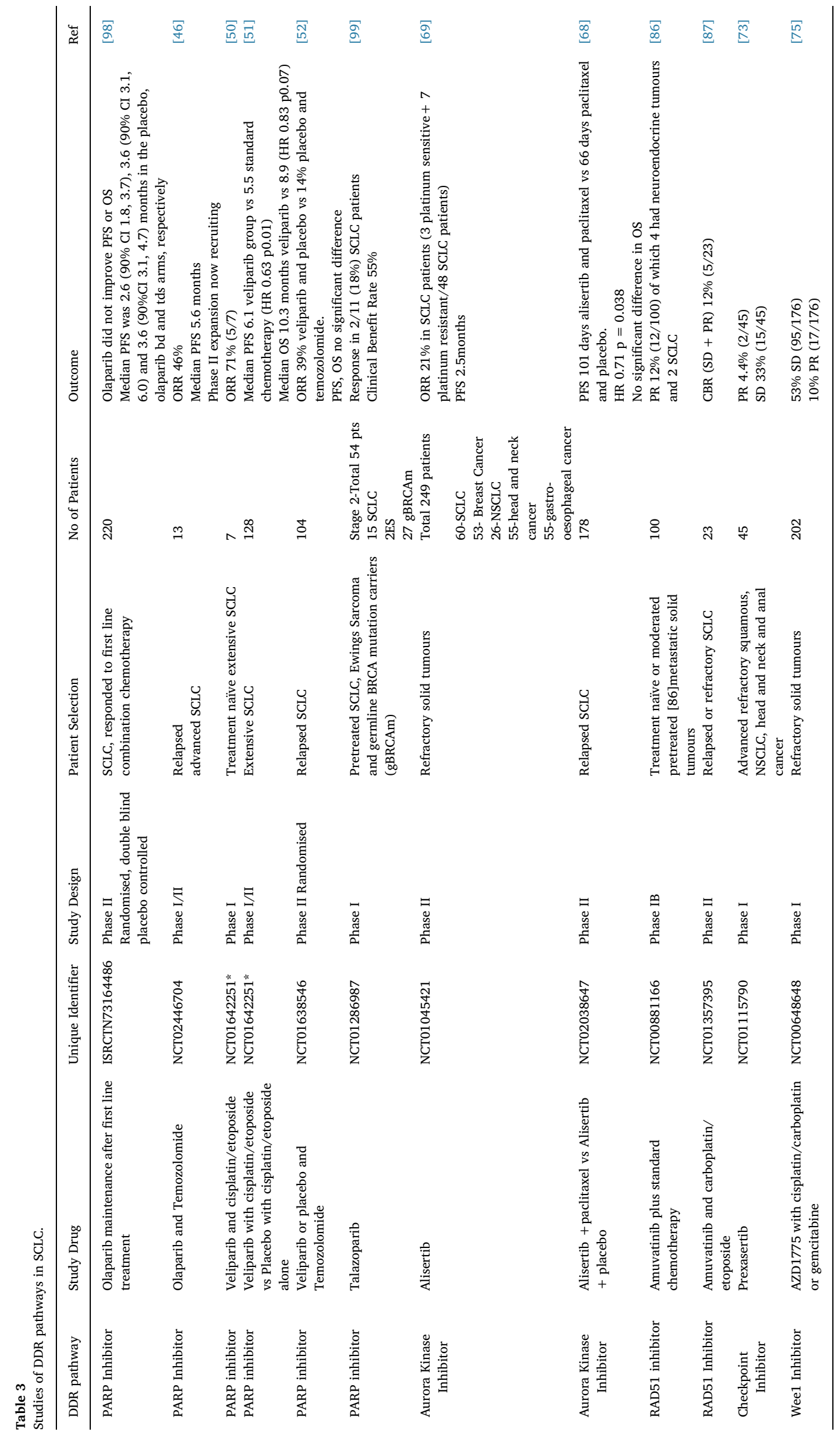

18

Downloaded for Anonymous User (n/a) at Centro Hospitalar Lisboa Central from ClinicalKey.com by Elsevier on November $29,2017$. For personal use only. No other uses without permission. Copyright $\odot 2017$. Elsevier Inc. All rights reserved. 
Interestingly a significantly different PFS was observed among the subgroup of 109 patients with resistant/refractory disease where a PFS of 2.86 months for alisertib and paclitaxel versus 1.64 months for alisertib and placebo ( $\mathrm{HR}=0.66, \mathrm{p}$ 0.032) was demonstrated. Furthermore, in an exploratory subgroup analysis according to expression of cmyc by IHC in archival tumour biopsies a median PFS of 4.64 months for alisertib and paclitaxel versus 2.27 months for placebo and paclitaxel (HR $=0.29, \mathrm{p}=0.0006)$ was observed. These results should be interpreted with caution due to a sample size of only 33 patients (17 and 16 per arm). However, in the c-myc negative group (13 patients, 6 and 7 per arm), the converse was observed with an inferior PFS for alisertib and paclitaxel of 3.32 months compared with a PFS of 5.16 months for placebo and paclitaxel (HR 11.8, p < 0.0006). Amplification and overexpression of the Myc family, a main driver oncogene dysregulated in many cancers and involved in the regulation of Aurora kinases transcription, occurs in $18-31 \%$ of SCLCs and may be more common in chemo-refractory disease [71]. Preclinical studies have demonstrated that aurora A kinase inhibitors are more effective in SCLC cell lines with myc family amplification [71] and/or high expression of myc [72]. A prospective study is now warranted to further evaluate the predictive significance of c-myc expression in the efficacy of alisertib and paclitaxel.

\subsection{Prexasertib}

Prexasertib is a selective ATP competitive inhibitor of CHK1 and CHK2. In preclinical studies, prexasertib has activity as a single agent and works synergistically with cytotoxic DNA damaging agents, inducing cell death in SCLC models [73]. A phase I trial of prexasertib in patients with advanced refractory squamous NSCLC, head and neck cancers and anal cancers reported a partial response (PR) of 4.4\% (2/ 45) and SD in 33\% (15/45) [74]. This agent is now being explored in extensive stage chemosensitive and chemoresistant SCLC (NCT0235980).

\section{3. $A Z D 1775$}

AZD1775 is an oral competitive inhibitor of Wee1. As a single agent AZD1775 is well tolerated with a favourable toxicity profile and potential to combine with cytotoxics or other DDR inhibitors [75]. A phase 1 trial of AZD1775 in combination with cisplatin, carboplatin or gemcitabine in 202 patients with refractory solid tumours demonstrated some clinical activity with $53 \%$ (95/176) of patients obtaining SD and $10 \%$ showing a PR. Of note, the response rates observed were higher in patients with mutated TP53 than those possessing TP53 wild type (21\% vs $12 \%)$ [76]. This agent is now being explored in a phase II clinical trial in patients with relapsed SCLC (NCT02593019) and in patients with relapsed SCLC harbouring a MYC amplification or CDKN2A mutation, combined with TP53 mutation in a phase II trial (NCT02688907). There is also promising preclinical data for the combination of AZD1775 and the PARP inhibitor, olaparib [77], and a phase I trial is in progress for patients with relapsed SCLC (NCT02511795).

\section{RAD51 inhibition}

RAD51 plays an essential role in homologous recombination and DNA repair [78]. In response to DNA damage the RAD51 protein relocates in the nucleus and it is thought to represent sites of DNA repair reactions [79]. RAD51 has the ability to promote joint molecule formation and DNA strand exchange between homologous DNA molecules [80-82]. In SCLC DSB repair after exposure to etoposide is RAD51 mediated [83].

\subsection{Amuvatinib}

Amuvatinib is a multi-targeted tyrosine kinase inhibitor, designed to inhibitor c-KIT and PDGFRa. In preclinical studies it was found to sensitise tumour cells to chemotherapy and radiotherapy in vitro supressing RAD51 $[84,85]$. Amuvatinib has demonstrated synergy with etoposide in SCLC cell lines and xenographs [86]

In preclinical studies Amuvatinib had synergistic effects with DNA damaging chemotherapies $[78,84]$. In a phase IB study in treatment naive patients receiving either paclitaxel/carboplatin or carboplatin/ etoposide in combination with amuvatinib for metastatic solid tumours, $12 \%$ demonstrated a partial response $(n=12 / 100)$, of which 4 had neuroendocrine tumours and 2 SCLC [87]. This prompted a phase 2 study in resistant relapsed SCLC with patients receiving amuvatinib in combination with carboplatin and etoposide (ESCAPE; TrEatment of Small Cell lung cancer with Amuvatinib in combination with Platinum Etoposide). A clinical benefit rate of $22 \%$ was reported which failed to meet the predefined study endpoint [88].

\section{ATR kinase inhibition}

The DDR pathway is regulated by a series of kinases including ataxia telangiectasia mutated (ATM) and ATM- and Rad3-related (ATR). ATM is activated by double strand breaks and ATR recruited to single stranded DNA coated with replication protein A, arising from DSBs or stalled DNA replication forks. ATR in turn activates Chk1 resulting in cell cycle arrest, promoting repair and preventing premature mitosis [89].

Disruption of the ATM/p53 pathway is observed in up to $70 \%$ of tumours and likely confers a growth advantage [90-92]. Disruption of the ATM pathway drives a reliance on the ATR pathway for DDR. Therefore inhibiting ATR in ATM deficient tumours may result in synthetic lethality [93].

\section{1. $V X-970$}

VX-970 is a potent and highly selective inhibitor of ATR. In a preclinical study VX-970 sensitized $80 \%$ of a panel of 35 lung cancer cell lines to cisplatin, with half of these demonstrating a greater than 10 fold increase in sensitivity. When the ATR inhibitor was compared to a Chk1 inhibitor the drugs displayed different sensitization profiles with VX-970 the most effective in combination with platinums and the Chk1 inhibitors most sensitizing to gemcitabine [94]. In the same study VX970 increased sensitivity to cisplatin in six out of seven NSCLC PDX models [94]. In addition, ATR inhibitors have been shown to increase sensitivity to topoisomerase I inhibitors in colorectal cancer cell lines in vitro and in vivo [95], rationalising the combination of ATR inhibitors and topotecan in early phase clinical trials in SCLC. Summary of DNA damage pathways and therapeutics (Fig. 3).

\section{Lurbinectidin}

Lurbinectedin is a novel anticancer drug that inhibits activated transcription, induces DNA double-strand breaks generating apoptosis, and modulates tumour microenvironment. The antitumor activity and safety of this agent in patients with SCLC has been assessed in three clinical trials: two phase I in combination with doxorubicin or paclitaxel and a phase II single- agent basket trial [96]. Activity is observed for single agent lurbinectidin (response rate $36 \%$ ) and in combination (response rates from 37 to $71 \%$ ). Haematological toxicity was significant with a grade $3 / 4$ neutropenia rate of $38 \%$ for single agent lurbinectidin. A phase III trial in the second line setting of lurbinectidin in combination with doxorubicin compared with standard second line therapy (topotecan or cyclophosphamide, doxorubicin and vincristine) is ongoing (ATLANTIS Study - NCT0256699). 


\section{Perspectives}

SCLC is a complex and heterogeneous tumour and the vast majority of patients will recur with a more resistant tumour. Several targeted agents have revolutionized the treatment of other cancers but despite decades of clinical trials none have been approved for clinical use. DDR inhibitors have demonstrated activity in patients with SCLC (see summary Table 3), although to date none have emerged with sufficient efficacy for routine clinical use. There is an unmet need to identify biomarkers that can stratify patients into advantageous groups. In fact an important limitation with the majority of trials has been the use of unselected patients within a heterogeneous cancer, in other words, targeted agents for untargeted tumours.

Currently PARP inhibitors are approved for use in BRCA mutated ovarian cancer. BRCA mutations are rare in SCLC but scoring systems have been proposed to predict for a 'BRCA like' genomic environment $[97,98]$. A novel 'DNA repair score' consisting of 17 DNA repair proteins, applied to SCLC cell lines and xenografts established that baseline activation of the PI3K/mTOR pathway is associated with resistance to the PARP inhibitor BMN673 [42]. Another biomarker, SLFN11 expression, is associated with PARP inhibitor sensitivity in SCLC cell lines and PDX models [44]. In addition, high levels of SLFN11 expression (Hscore $>=1$ ) were associated with a trend toward improved OS and favourable tumour responses in patients with recurrent SCLC that received TMZ and Veliparib as second line regiment, but not temozolomide plus placebo in a randomised phase II clinical trial [99] highlighting evident biomarkers that could guide clinical decision making.

These biomarkers are dynamic and longitudinal sampling will be required to tailor a personalised medicine approach. As a case in point, using co-clinical models of CTC derived explant or tumour biopsy derived explant tumours the expression of SLFN11 and MGMT, biomarkers for activity of olaparib and TMZ, respectively, did not consistently correlate with the tumour responses observed to these drugs in the donor patients [47]. Correlation of identified scoring systems in clinical studies of PARP inhibition in SCLC will be important to identity patients most likely to benefit from treatment.

In conclusion, exploration of biomarkers in vivo, from diagnostic tumour biopsies and liquid biopsies will be crucial in identifying patients who will derive clinical benefit from DDR inhibitors. While targeting DDR mechanisms is theoretically plausible the results from clinical trials to date have yet to convince. Further investigation into the synergistic effects of DDR inhibitors administered in combination with traditional DNA damaging therapies will expand our understanding of how these agents are best positioned in the clinical setting and biomarker studies may provide insight into mechanisms of acquired and inherent resistance.

\section{Conflicts of interest}

Fiona Blackhall has received consulting fees or honoraria from AstraZeneca, Pfizer, Boehring-Ingelheim, Medivation, Novartis, MSD and BMS. Fiona Blackhall has received research funding from Abbvie, AstraZeneca, Amgen and IMSWorld.

\section{Acknowledgements}

Victoria Foy was funded by a CRUK-AstraZeneca Fellowship grant. Maximillian Schenk was funded by a CRUK PhD studentship. Katie Baker was funded by a CRUK Lung Cancer Centre of Excellence grant.

\section{References}

[1] D.R. Youlden, S.M. Cramb, P.D. Baade, The International Epidemiology of Lung Cancer: geographical distribution and secular trends, J. Thor. Oncol. 3 (8) (2008) 819-831.

[2] A. Thomas, Y. Pommier, Small cell lung cancer: time to revisit DNA-damaging chemotherapy, Sci. Transl. Med. 8 (346) (2016) 346fs12.

[3] J. George, J.S. Lim, S.J. Jang, Y. Cun, L. Ozretic, G. Kong, F. Leenders, X. Lu, L. Fernandez-Cuesta, G. Bosco, C. Muller, I. Dahmen, N.S. Jahchan, K.S. Park, D. Yang, A.N. Karnezis, D. Vaka, A. Torres, M.S. Wang, J.O. Korbel, R. Menon, S.M. Chun, D. Kim, M. Wilkerson, N. Hayes, D. Engelmann, B. Putzer, M. Bos, S. Michels, I. Vlasic, D. Seidel, B. Pinther, P. Schaub, C. Becker, J. Altmuller, J. Yokota, T. Kohno, R. Iwakawa, K. Tsuta, M. Noguchi, T. Muley, H. Hoffmann, P.A. Schnabel, I. Petersen, Y. Chen, A. Soltermann, V. Tischler, C.M. Choi, Y.H. Kim, P.P. Massion, Y. Zou, D. Jovanovic, M. Kontic, G.M. Wright, P.A. Russell, B. Solomon, I. Koch, M. Lindner, L.A. Muscarella, A. la Torre, J.K. Field, M. Jakopovic, J. Knezevic, E. Castanos-Velez, L. Roz, U. Pastorino, O.T. Brustugun, M. Lund-Iversen, E. Thunnissen, J. Kohler, M. Schuler, J. Botling, M. Sandelin, M. Sanchez-Cespedes, H.B. Salvesen, V. Achter, U. Lang, M. Bogus, P.M. Schneider, T. Zander, S. Ansen, M. Hallek, J. Wolf, M. Vingron, Y. Yatabe, W.D. Travis, P. Nurnberg, C. Reinhardt, S. Perner, L. Heukamp, R. Buttner, S.A. Haas, E. Brambilla, M. Peifer, J. Sage, R.K. Thomas, Comprehensive genomic profiles of small cell lung cancer, Nature 524 (7563) (2015) 47-53.

[4] G. Alvarado-Luna, D. Morales-Espinosa, Treatment for small cell lung cancer, where are we now? - a review, Transl. Lung Cancer Res. 5 (1) (2016) 26-38.

[5] D.M. Jackman, B.E. Johnson, Small-cell lung cancer, Lancet 366 (9494) (2005) 1385-1396.

[6] C. Faivre-Finn, M. Snee, L. Ashcroft, W. Appel, F. Barlesi, A. Bhatnagar, A. Bezjak, F. Cardenal, P. Fournel, S. Harden, C. Le Pechoux, R. McMenemin, N. Mohammed, M. O'Brien, J. Pantarotto, V. Surmont, J.P. Van Meerbeeck, P.J. Woll, P. Lorigan, F. Blackhall, Concurrent once-daily versus twice-daily chemoradiotherapy in patients with limited-stage small-cell lung cancer (CONVERT): an open-label, phase 3, randomised, superiority trial, Lancet Oncol. 18 (8) (2017) 1116-1125.

[7] M. Tiseo, L. Boni, F. Ambrosio, A. Camerini, E. Baldini, S. Cinieri, M. Brighenti, F. Zanelli, E. Defraia, R. Chiari, C. Dazzi, C. Tibaldi, G.M. Turolla, V. D’Alessandro, N. Zilembo, A.R. Trolese, F. Grossi, F. Riccardi, A. Ardizzoni, Italian, multicenter, phase III, randomized study of cisplatin plus etoposide with or without bevacizumab as first-line treatment in extensive-disease small-cell lung cancer: the GOIRC-AIFA FARM6PMFJM trial, J. Clin. Oncol. 35 (12) (2017) 1281-1287.

[8] J. von Pawel, J.H. Schiller, F.A. Shepherd, S.Z. Fields, J.P. Kleisbauer, N.G. Chrysson, D.J. Stewart, P.I. Clark, M.C. Palmer, A. Depierre, J. Carmichael, J.B. Krebs, G. Ross, S.R. Lane, R. Gralla, Topotecan versus cyclophosphamide, doxorubicin, and vincristine for the treatment of recurrent small-cell lung cancer, J. Clin. Oncol. 17 (2) (1999) 658.

[9] M. Fruh, D. De Ruysscher, S. Popat, L. Crino, S. Peters, E. Felip, E.G.W. Group, Small-cell lung cancer (SCLC): ESMO Clinical Practice Guidelines for diagnosis, treatment and follow-up, Ann. Oncol. 24 (Suppl. 6) (2013) vi99-vi105.

[10] L.A. Byers, C.M. Rudin, Small cell lung cancer: where do we go from here? Cancer 121 (5) (2015) 664-672.

[11] Y.H. Kim, K. Goto, K. Yoh, S. Niho, H. Ohmatsu, K. Kubota, N. Saijo, Y. Nishiwaki, Performance status and sensitivity to first-line chemotherapy are significant prognostic factors in patients with recurrent small cell lung cancer receiving second-line chemotherapy, Cancer 113 (9) (2008) 2518-2523.

[12] P.E. Postmus, H.H. Berendsen, N. van Zandwijk, T.A. Splinter, J.T. Burghouts, W. Bakker, Retreatment with the induction regimen in small cell lung cancer relapsing after an initial response to short term chemotherapy, Eur. J. Cancer Clin. Oncol. 23 (9) (1987) 1409-1411.

[13] G. Giaccone, M. Donadio, G. Bonardi, F. Testore, A. Calciati, Teniposide in the treatment of small-cell lung cancer: the influence of prior chemotherapy, J. Clin. Oncol. 6 (8) (1988) 1264-1270.

[14] T.K. Owonikoko, M. Behera, Z. Chen, C. Bhimani, W.J. Curran, F.R. Khuri, S.S. Ramalingam, A systematic analysis of efficacy of second-line chemotherapy in sensitive and refractory small-cell lung cancer, J. Thor. Oncol. 7 (5) (2012) 866-872.

[15] A. Ardizzoni, M. Tiseo, L. Boni, Validation of standard definition of sensitive versus refractory relapsed small cell lung cancer: a pooled analysis of topotecan secondline trials, Eur. J. Cancer (Oxford, England: 1990) 50 (13) (2014) 2211-2218.

[16] M.J. O'Connor, Targeting the DNA damage response in cancer, Mol. Cell 60 (4) (2015) 547-560.

[17] L.H. Pearl, A.C. Schierz, S.E. Ward, B. Al-Lazikani, F.M. Pearl, Therapeutic opportunities within the DNA damage response, Nat. Rev. Cancer 15 (3) (2015) 166-180.

[18] L.B. Alexandrov, S. Nik-Zainal, D.C. Wedge, S.A. Aparicio, S. Behjati, A.V. Biankin, G.R. Bignell, N. Bolli, A. Borg, A.L. Borresen-Dale, S. Boyault, B. Burkhardt, A.P. Butler, C. Caldas, H.R. Davies, C. Desmedt, R. Eils, J.E. Eyfjord, J.A. Foekens, M. Greaves, F. Hosoda, B. Hutter, T. Ilicic, S. Imbeaud, M. Imielinski, N. Jager, D.T. Jones, D. Jones, S. Knappskog, M. Kool, S.R. Lakhani, C. Lopez-Otin, S. Martin, N.C. Munshi, H. Nakamura, P.A. Northcott, M. Pajic, E. Papaemmanuil, A. Paradiso, J.V. Pearson, X.S. Puente, K. Raine, M. Ramakrishna, A.L. Richardson, J. Richter, P. Rosenstiel, M. Schlesner, T.N. Schumacher, P.N. Span, J.W. Teague, Y. Totoki, A.N. Tutt, R. Valdes-Mas, M.M. van Buuren, L. van 't Veer, A. Vincent-Salomon, N. Waddell, L.R. Yates, J. Zucman-Rossi, P.A. Futreal, U. McDermott, P. Lichter, M. Meyerson, S.M. Grimmond, R. Siebert, E. Campo, T. Shibata, S.M. Pfister, P.J. Campbell, M.R. Stratton, Signatures of mutational processes in human cancer, Nature 500 (7463) (2013) 415-421.

[19] C.M. Rudin, S. Durinck, E.W. Stawiski, J.T. Poirier, Z. Modrusan, D.S. Shames, E.A. Bergbower, Y. Guan, J. Shin, J. Guillory, C.S. Rivers, C.K. Foo, D. Bhatt, J. Stinson, F. Gnad, P.M. Haverty, R. Gentleman, S. Chaudhuri, V. Janakiraman, B.S. Jaiswal, C. Parikh, W. Yuan, Z. Zhang, H. Koeppen, T.D. Wu, H.M. Stern, R.L. Yauch, K.E. Huffman, D.D. Paskulin, P.B. Illei, M. Varella-Garcia, A.F. Gazdar, F.J. de Sauvage, R. Bourgon, J.D. Minna, M.V. Brock, S. Seshagiri, Comprehensive genomic analysis identifies SOX2 as a frequently amplified gene in small-cell lung cancer, Nat. Genet. 44 (10) (2012) 1111-1116. 
[20] A. Dowlati, M.B. Lipka, K. McColl, S. Dabir, M. Behtaj, A. Kresak, A. Miron, M. Yang, N. Sharma, P. Fu, G. Wildey, Clinical correlation of extensive-stage smallcell lung cancer genomics, Ann. Oncol. 27 (4) (2016) 642-647.

[21] M. Peifer, L. Fernandez-Cuesta, M.L. Sos, J. George, D. Seidel, L.H. Kasper, D. Plenker, F. Leenders, R. Sun, T. Zander, R. Menon, M. Koker, I. Dahmen, C. Muller, V. Di Cerbo, H.U. Schildhaus, J. Altmuller, I. Baessmann, C. Becker, B. de Wilde, J. Vandesompele, D. Bohm, S. Ansen, F. Gabler, I. Wilkening, S. Heynck, J.M. Heuckmann, X. Lu, S.L. Carter, K. Cibulskis, S. Banerji, G. Getz, K.S. Park, D. Rauh, C. Grutter, M. Fischer, L. Pasqualucci, G. Wright, Z. Wainer, P. Russell, I. Petersen, Y. Chen, E. Stoelben, C. Ludwig, P. Schnabel, H. Hoffmann, T. Muley, M. Brockmann, W. Engel-Riedel, L.A. Muscarella, V.M. Fazio, H. Groen, W. Timens, H. Sietsma, E. Thunnissen, E. Smit, D.A. Heideman, P.J. Snijders, F. Cappuzzo, C. Ligorio, S. Damiani, J. Field, S. Solberg, O.T. Brustugun, M. Lund-Iversen, J. Sanger, J.H. Clement, A. Soltermann, H. Moch, W. Weder, B. Solomon, J.C. Soria, P. Validire, B. Besse, E. Brambilla, C. Brambilla, S. Lantuejoul, P. Lorimier, P.M. Schneider, M. Hallek, W. Pao, M. Meyerson, J. Sage, J. Shendure, R. Schneider, R. Buttner, J. Wolf, P. Nurnberg, S. Perner, L.C. Heukamp, P.K. Brindle, S. Haas, R.K. Thomas, Integrative genome analyses identify key somatic driver mutations of small-cell lung cancer, Nat. Genet. 44 (10) (2012) 1104-1110.

[22] T.S. Byun, M. Pacek, M.C. Yee, J.C. Walter, K.A. Cimprich, Functional uncoupling of MCM helicase and DNA polymerase activities activates the ATR-dependent checkpoint, Genes Dev. 19 (9) (2005) 1040-1052.

[23] A. Mazouzi, G. Velimezi, J.I. Loizou, DNA replication stress: causes, resolution and disease, Exp. Cell Res. 329 (1) (2014) 85-93.

[24] P. Bouwman, J. Jonkers, The effects of deregulated DNA damage signalling on cancer chemotherapy response and resistance, Nat. Rev. Cancer 12 (9) (2012) 587-598.

[25] L. Amable, Cisplatin resistance and opportunities for precision medicine, Pharmacol. Res. 106 (2016) 27-36.

[26] S. Dasari, P.B. Tchounwou, Cisplatin in cancer therapy: molecular mechanisms of action, Eur. J. Pharmacol. 740 (2014) 364-378.

[27] D. Wang, S.J. Lippard, Cellular processing of platinum anticancer drugs, Nat. Rev. Drug Discov. 4 (4) (2005) 307-320.

[28] D.J. Beck, R.R. Brubaker, Effect of cis-platinum(II)diamminodichloride on wild type and deoxyribonucleic acid repair deficient mutants of Escherichia coli, J. Bacteriol. 116 (3) (1973) 1247-1252.

[29] M. Biggerstaff, R.D. Wood, Requirement for ERCC-1 and ERCC-3 gene products in DNA excision repair in vitro. Complementation using rodent and human cell extracts, J. Biol. Chem. 267 (10) (1992) 6879-6885.

[30] R. Metzger, C.G. Leichman, K.D. Danenberg, P.V. Danenberg, H.J. Lenz, K. Hayashi, S. Groshen, D. Salonga, H. Cohen, L. Laine, P. Crookes, H. Silberman, J. Baranda, B. Konda, L. Leichman, ERCC1 mRNA levels complement thymidylate synthase mRNA levels in predicting response and survival for gastric cancer patients receiving combination cisplatin and fluorouracil chemotherapy, J. Clin. Oncol. 16 (1) (1998) 309-316.

[31] P. Ceppi, M. Longo, M. Volante, S. Novello, S. Cappia, E. Bacillo, G. Selvaggi, S. Saviozzi, R. Calogero, M. Papotti, G.V. Scagliotti, Excision repair cross complementing-1 and topoisomerase IIalpha gene expression in small-cell lung cancer patients treated with platinum and etoposide: a retrospective study, J. Thorac. Oncol. 3 (6) (2008) 583-589.

[32] N. Karachaliou, C. Papadaki, E. Lagoudaki, M. Trypaki, M. Sfakianaki, A. Koutsopoulos, D. Mavroudis, E. Stathopoulos, V. Georgoulias, J. Souglakos, Predictive value of BRCA1, ERCC1, ATP7B, PKM2, TOPOI, TOPO-IIA, TOPOIIB and C-MYC genes in patients with small cell lung cancer (SCLC) who received first line therapy with cisplatin and etoposide, PLoS One 8 (9) (2013) e74611.

[33] A.M. Dingemans, M.A. Witlox, R.A. Stallaert, P. van der Valk, P.E. Postmus, G. Giaccone, Expression of DNA topoisomerase IIalpha and topoisomerase IIbeta genes predicts survival and response to chemotherapy in patients with small cell lung cancer, Clin. Cancer Res. 5 (8) (1999) 2048-2058.

[34] M.D. Garrett, I. Collins, Anticancer therapy with checkpoint inhibitors: what, where and when? Trends Pharmacol. Sci. 32 (5) (2016) 308-316.

[35] N.J. Curtin, DNA repair dysregulation from cancer driver to therapeutic target, Nat. Rev. Cancer 12 (12) (2012) 801-817.

[36] L.A. Byers, J. Wang, M.B. Nilsson, J. Fujimoto, P. Saintigny, J. Yordy, U. Giri, M. Peyton, Y.H. Fan, L. Diao, F. Masrorpour, L. Shen, W. Liu, B. Duchemann, P. Tumula, V. Bhardwaj, J. Welsh, S. Weber, B.S. Glisson, N. Kalhor, I.I. Wistuba, L. Girard, S.M. Lippman, G.B. Mills, K.R. Coombes, J.N. Weinstein, J.D. Minna, J.V. Heymach, Proteomic profiling identifies dysregulated pathways in small cell lung cancer and novel therapeutic targets including PARP1, Cancer Discov. 2 (9) (2012) 798-811.

[37] H.E. Bryant, N. Schultz, H.D. Thomas, K.M. Parker, D. Flower, E. Lopez, S. Kyle, M. Meuth, N.J. Curtin, T. Helleday, Specific killing of BRCA2-deficient tumours with inhibitors of poly(ADP-ribose) polymerase, Nature 434 (7035) (2005) 913-917.

[38] J. Murai, S.Y. Huang, B.B. Das, A. Renaud, Y. Zhang, J.H. Doroshow, J. Ji, S. Takeda, Y. Pommier, Trapping of PARP1 and PARP2 by clinical PARP inhibitors, Cancer Res. 72 (21) (2012) 5588-5599.

[39] H. Farmer, N. McCabe, C.J. Lord, A.N. Tutt, D.A. Johnson, T.B. Richardson, M. Santarosa, K.J. Dillon, I. Hickson, C. Knights, N.M. Martin, S.P. Jackson, G.C. Smith, A. Ashworth, Targeting the DNA repair defect in BRCA mutant cells as a therapeutic strategy, Nature 434 (7035) (2005) 917-921.

[40] G. Kim, G. Ison, A.E. McKee, H. Zhang, S. Tang, T. Gwise, R. Sridhara, E. Lee, A. Tzou, R. Philip, H.J. Chiu, T.K. Ricks, T. Palmby, A.M. Russell, G. Ladouceur, E. Pfuma, H. Li, L. Zhao, Q. Liu, R. Venugopal, A. Ibrahim, R. Pazdur, FDA approval summary olaparib monotherapy in patients with deleterious germline BRCAMutated advanced ovarian cancer treated with three or more lines of chemotherapy, Clin. Cancer Res. 21 (19) (2015) 4257-4261.

[41] B.H. Lok, E.E. Gardner, V.E. Schneeberger, A. Ni, P. Desmeules, N. Rekhtman, E. de Stanchina, B.A. Teicher, N. Riaz, S.N. Powell, J.T. Poirier, C.M. Rudin, PARP inhibitor activity correlates with SLFN11 expression and demonstrates synergy with temozolomide in small cell lung cancer, Clin. Cancer Res. 23 (2) (2017) 523-535.

[42] R.J. Cardnell, Y. Feng, L. Diao, Y.H. Fan, F. Masrorpour, J. Wang, Y. Shen, G.B. Mills, J.D. Minna, J.V. Heymach, L.A. Byers, Proteomic markers of DNA repair and PI3K pathway activation predict response to the PARP inhibitor BMN 673 in small cell lung cancer, Clin. Cancer Res. 19 (22) (2013) 6322-6328.

[43] J. Murai, Y. Zhang, J. Morris, J. Ji, S. Takeda, J.H. Doroshow, Y. Pommier, Rationale for poly(ADP-ribose) polymerase (PARP) inhibitors in combination therapy with camptothecins or temozolomide based on PARP trapping versus catalytic inhibition, J. Pharmacol. Exp. Ther. 349 (3) (2014) 408-416.

[44] B.H. Lok, E.E. Gardner, V.E. Schneeberger, A. Ni, P. Desmeules, N. Rekhtman, E. de Stanchina, B.A. Teicher, N. Riaz, S.N. Powell, J.T. Poirier, C.M. Rudin, PARP inhibitor activity correlates with SLFN11 expression and demonstrates synergy with temozolomide in small cell lung cancer, Clin. Cancer Res. 23 (2) (2017) 523-535.

[45] L.A. Byers, J. Wang, M.B. Nilsson, J. Fujimoto, P. Saintigny, J. Yordy, U. Giri, M. Peyton, Y.H. Fan, L. Diao, F. Masrorpour, L. Shen, W. Liu, B. Duchemann, P. Tumula, V. Bhardwaj, J. Welsh, S. Weber, B.S. Glisson, N. Kalhor, I.I. Wistuba, L. Girard, S.M. Lippman, G.B. Mills, K.R. Coombes, J.N. Weinstein, J.D. Minna, J.V. Heymach, Proteomic profiling identifies dysregulated pathways in small cell lung cancer and novel therapeutic targets including PARP1, Cancer Discov. 2 (9) (2012) 798-811.

[46] P.J.E.A. Woll, STOMP: small cell lung cancer trial of olaparib (AZD2281) as maintenance programme - a randomised, double blind, multicentre NCRN phase II trial, Lung Cancer (Amsterdam, Netherlands) 71 (2017) S42.

[47] A.F. Farago, B.J. Drapkin, A. Charles, B. Yeap, R.S. Heist, C.G. Azzoli, D.M. Jackman, D.A. Barbie, E. Choy, L.V. Sequist, S. Maheswaran, D.A. Haber, A.N. Hata, N. Dyson, A.T. Shaw, Abstract CT048: Phase 1/2 study of olaparib tablets and temozolomide in patients with small cell lung cancer (SCLC) following failure of prior chemotherapy, Cancer Res. 77 (13 Supplement) (2017) CT048.

[48] C.L. Hodgkinson, C.J. Morrow, Y. Li, R.L. Metcalf, D.G. Rothwell, F. Trapani, R. Polanski, D.J. Burt, K.L. Simpson, K. Morris, S.D. Pepper, D. Nonaka, A. Greystoke, P. Kelly, B. Bola, M.G. Krebs, J. Antonello, M. Ayub, S. Faulkner, L. Priest, L. Carter, C. Tate, C.J. Miller, F. Blackhall, G. Brady, C. Dive, Tumorigenicity and genetic profiling of circulating tumor cells in small-cell lung cancer, Nat. Med. 20 (8) (2014) 897-903.

[49] V.C. Daniel, L. Marchionni, J.S. Hierman, J.T. Rhodes, W.L. Devereux, C.M. Rudin, R. Yung, G. Parmigiani, M. Dorsch, C.D. Peacock, D.N. Watkins, A primary xenograft model of small-cell lung cancer reveals irreversible changes in gene expression imposed by culture in vitro, Cancer Res. 69 (8) (2009) 3364-3373.

[50] F.J. Rossello, R.W. Tothill, K. Britt, K.D. Marini, J. Falzon, D.M. Thomas, C.D. Peacock, L. Marchionni, J. Li, S. Bennett, E. Tantoso, T. Brown, P. Chan, L.G. Martelotto, D.N. Watkins, Next-generation sequence analysis of cancer xenograft models, PLoS One 8 (9) (2013) e74432.

[51] T.K. Owonikoko, S.E. Dahlberg, S.A. Khan, D.E. Gerber, J. Dowell, R.A. Moss, C.P. Belani, C.L. Hann, C. Aggarwal, S.S. Ramalingam, A phase 1 safety study of veliparib combined with cisplatin and etoposide in extensive stage small cell lung cancer: a trial of the ECOG-ACRIN Cancer Research Group (E2511), Lung Cancer (Amsterdam, Netherlands) 89 (1) (2015) 66-70.

[52] T.F. Owonikoko, G. Sica, et al., Randomized trial of cisplatin and etoposide in combination with veliparib or placebo for extensive stage small cell lung cancer: ECOG-ACRIN 2511 study, J. Clin. Oncol. 34 (suppl abstr 8505) (2017).

[53] M.C. Pietanza, L.M. Krug, S.N. Waqar, A. Dowlati, C.L. Hann, A. Chiappori, T.K. Owonikoko, K. Woo, Y. Bensman, B. Hurtado, J. Fujimoto, I.I. Wistuba, W.D. Travis, A.P. Chen, J. Heymach, M.G. Kris, M. Fleisher, C.M. Rudin, L.A. Byers, A multi-center, randomized, double-blind phase II study comparing temozolomide (TMZ) plus either veliparib (ABT-888), a PARP inhibitor, or placebo as 2nd or 3rdline therapy for patients (Pts) with relapsed small cell lung cancers (SCLCs), J. Clin. Oncol. 34 (15_suppl) (2016) 8512.

[54] Y. Mu, J. Lou, M. Srivastava, B. Zhao, X.H. Feng, T. Liu, J. Chen, J. Huang, SLFN11 inhibits checkpoint maintenance and homologous recombination repair, EMBO Rep. 17 (1) (2016) 94-109.

[55] J. Murai, Y. Feng, G.K. Yu, Y. Ru, S.-W. Tang, Y. Shen, Y. Pommier, Resistance to PARP inhibitors by SLFN11 inactivation can be overcome by ATR inhibition, Oncotarget 7 (47) (2016) 76534-76550.

[56] J.K. Sabari, B.H. Lok, J.H. Laird, J.T. Poirier, C.M. Rudin, Unravelling the biology of SCLC: implications for therapy, Nat. Rev. Clin. Oncol. 14 (9) (2017) 549-561.

[57] E.E. Gardner, B.H. Lok, V.E. Schneeberger, P. Desmeules, L.A. Miles, P.K. Arnold, A. Ni, I. Khodos, E. de Stanchina, T. Nguyen, J. Sage, J.E. Campbell, S. Ribich, N. Rekhtman, A. Dowlati, P.P. Massion, C.M. Rudin, J.T. Poirier, Chemosensitive relapse in small cell lung cancer proceeds through an EZH2-SLFN11 axis, Cancer Cell 31 (2) (2017) 286-299.

[58] J. Murai, S.-Y.N. Huang, A. Renaud, Y. Zhang, J. Ji, S. Takeda, J. Morris, B. Teicher, J.H. Doroshow, Y. Pommier, Stereospecific PARP trapping by BMN 673 and comparison with olaparib and rucaparib, Mol. Cancer Ther. 13 (2) (2014) 433-443.

[59] J. de Bono, R.K. Ramanathan, L. Mina, R. Chugh, J. Glaspy, S. Rafii, S. Kaye, J. Sachdev, J. Heymach, D.C. Smith, J.W. Henshaw, A. Herriott, M. Patterson, N.J. Curtin, L.A. Byers, Z.A. Wainberg, I. Phase, Two-Part trial of the PARP inhibitor talazoparib in patients with advanced germline BRCA1/2 mutations and selected sporadic cancers, Cancer Discov. 7 (6) (2017) 620-629.

[60] S. Hayama, Y. Daigo, T. Yamabuki, D. Hirata, T. Kato, M. Miyamoto, T. Ito, E. Tsuchiya, S. Kondo, Y. Nakamura, Phosphorylation and activation of cell division cycle associated 8 by aurora kinase B plays a significant role in human lung carcinogenesis, Cancer Res. 67 (9) (2007) 4113-4122. 
[61] R.G. Syljuasen, G. Hasvold, S. Hauge, A. Helland, Targeting lung cancer through inhibition of checkpoint kinases, Front. Genet. 6 (2015) 70.

[62] M. Maugeri-Sacca, M. Bartucci, R. De Maria, Checkpoint kinase 1 inhibitors for potentiating systemic anticancer therapy, Cancer Treat. Rev. 39 (5) (2013) 525-533.

[63] S. Mueller, D.A. Haas-Kogan, WEE1 kinase As a target for cancer therapy, J. Clin. Oncol. 33 (30) (2015) 3485-3487.

[64] S.E. Mir, P.C. De Witt Hamer, P.M. Krawczyk, L. Balaj, A. Claes, J.M. Niers, A.A. Van Tilborg, A.H. Zwinderman, D. Geerts, G.J. Kaspers, W. Peter Vandertop, J. Cloos, B.A. Tannous, P. Wesseling, J.A. Aten, D.P. Noske, C.J. Van Noorden, T. Wurdinger, In silico analysis of kinase expression identifies WEE1 as a gatekeeper against mitotic catastrophe in glioblastoma, Cancer Cell 18 (3) (2010) 244-257.

[65] M. Aarts, R. Sharpe, I. Garcia-Murillas, H. Gevensleben, M.S. Hurd, S.D. Shumway, C. Toniatti, A. Ashworth, N.C. Turner, Forced mitotic entry of S-phase cells as a therapeutic strategy induced by inhibition of WEE1, Cancer Discov. 2 (6) (2012) 524-539.

[66] T. Kogiso, H. Nagahara, E. Hashimoto, S. Ariizumi, M. Yamamoto, K. Shiratori, Efficient induction of apoptosis by wee1 kinase inhibition in hepatocellular carcinoma cells, PLoS One 9 (6) (2014) e100495.

[67] W.N. Pappano, Q. Zhang, L.A. Tucker, C. Tse, J. Wang, Genetic inhibition of the atypical kinase Wee1 selectively drives apoptosis of p53 inactive tumor cells, BMC Cancer 14 (2014) 430.

[68] P.S. Harris, S. Venkataraman, I. Alimova, D.K. Birks, I. Balakrishnan, B. Cristiano, A.M. Donson, A.M. Dubuc, M.D. Taylor, N.K. Foreman, P. Reigan, R. Vibhakar, Integrated genomic analysis identifies the mitotic checkpoint kinase WEE1 as a novel therapeutic target in medulloblastoma, Mol. Cancer 13 (2014) 72.

[69] T. Owonikoko, K. Nackaerts, T. Csoszi, G. Ostoros, C. Baik, C.D. Ullmann, E. Zagadailov, E. Sheldon-Waniga, D. Huebner, E.J. Leonard, D. Spigel, OA05.05 randomized phase 2 study: alisertib (MLN8237) or placebo + paclitaxel as secondline therapy for small-cell lung cancer (SCLC), J. Thorac. Oncol. 12 (1) (2016) S261-S262.

[70] B. Melichar, A. Adenis, A.C. Lockhart, J. Bennouna, E.C. Dees, O. Kayaleh, R. Obermannova, A. DeMichele, P. Zatloukal, B. Zhang, C.D. Ullmann, C. Schusterbauer, Safety and activity of alisertib, an investigational aurora kinase A inhibitor, in patients with breast cancer, small-cell lung cancer, non-small-cell lung cancer, head and neck squamous-cell carcinoma, and gastro-oesophageal adenocarcinoma: a five-arm phase 2 study, Lancet Oncol. 16 (4) (2015) 395-405.

[71] M.L. Sos, F. Dietlein, M. Peifer, J. Schöttle, H. Balke-Want, C. Müller, M. Koker, A. Richters, S. Heynck, F. Malchers, J.M. Heuckmann, D. Seidel, P.A. Eyers, R.T. Ullrich, A.P. Antonchick, V.V. Vintonyak, P.M. Schneider, T. Ninomiya, H. Waldmann, R. Büttner, D. Rauh, L.C. Heukamp, R.K. Thomas, A framework for identification of actionable cancer genome dependencies in small cell lung cancer, Proc. Natl. Acad. Sci. 109 (42) (2012) 17034-17039.

[72] K.E. Hook, A. Pavlicek, S.J. Garza, M.E. Lira, K. Ching, J. Kan, S.P. Srinivasa, J.G. Christensen, Abstract 2615: Amplification and/or high expression of Myc family genes sensitizes tumor cells to aurora kinase inhibitors, Cancer Res. 70 (8 Supplement) (2010) 2615

[73] T. Sen, P. Tong, C.A. Stewart, S. Cristea, A. Valliani, D.S. Shames, A. Redwood, Y. Fan, L. Li, B.S. Glisson, J. Minna, J. Sage, D.L. Gibbons, H. Piwnica-Worms, J. Heymach, J. Wang, L.A. Byers, CHK1 inhibition in small cell lung cancer produces single-agent activity in biomarker-defined disease subsets and combination activity with cisplatin or olaparib, Cancer Res. 77 (14) (2017) 3870-3884.

[74] D. Hong, J. Infante, F. Janku, S. Jones, L.M. Nguyen, H. Burris, A. Naing, T.M. Bauer, S. Piha-Paul, F.M. Johnson, R. Kurzrock, L. Golden, S. Hynes, J. Lin, A.B. Lin, J. Bendell, I study of LY2606368, a checkpoint kinase 1 inhibitor, in patients with advanced cancer, J. Clin. Oncol. 34 (15) (2016) 1764-1771.

[75] K. Do, D. Wilsker, J. Ji, J. Zlott, T. Freshwater, R.J. Kinders, J. Collins, A.P. Chen, J.H. Doroshow, S. Kummar, Phase I study of single-agent AZD1775 (MK-1775), a wee1 kinase inhibitor, in patients with refractory solid tumors, J. Clin. Oncol. 33 (30) (2015) 3409-3415.

[76] S. Leijen, R.M.J.M.V. Geel, A.C. Pavlick, R. Tibes, L. Rosen, A.R.A. Razak, R. Lam, T. Demuth, S. Rose, M.A. Lee, T. Freshwater, S. Shumway, L.W. Liang, A.M. Oza, J.H.M. Schellens, G.I. Shapiro, Phase I study evaluating WEE1 inhibitor AZD1775 As monotherapy and in combination with gemcitabine, cisplatin, or carboplatin in patients with advanced solid tumors, J. Clin. Oncol. 34 (36) (2016) 4371-4380.

[77] E.P. Hamilton, G. Falchook, et al., A phase Ib study of AZD1775 and olaparib combination in patients with refractory solid tumors, J. Clin. Oncol. 34 (2016) abstr 5562).

[78] W. Henning, H.W. Sturzbecher, Homologous recombination and cell cycle checkpoints: Rad51 in tumour progression and therapy resistance, Toxicology 193 (1-2) (2003) 91-109.

[79] M. Tarsounas, A.A. Davies, S.C. West, RAD51 localization and activation following DNA damage, Phil. Trans. R. Soc. B : Biol. Sci. 359 (1441) (2004) 87-93.

[80] F.E. Benson, A. Stasiak, S.C. West, Purification and characterization of the human Rad51 protein, an analogue of E. coli RecA, EMBO J. 13 (23) (1994) 5764-5771.

[81] P. Baumann, F.E. Benson, S.C. West, Human Rad51 protein promotes ATP-dependent homologous pairing and strand transfer reactions in vitro, Cell 87 (4) (1996) 757-766.

[82] R.C. Gupta, L.R. Bazemore, E.I. Golub, C.M. Radding, Activities of human recombination protein Rad51, Proc. Natl. Acad. Sci. U. S. A. 94 (2) (1997) 463-468.

[83] L.T. Hansen, C. Lundin, M. Spang-Thomsen, L.N. Petersen, T. Helleday, The role of RAD51 in etoposide (VP16) resistance in small cell lung cancer, Int. J. Cancer 105
(4) (2003) 472-479.

[84] J.W. Welsh, D. Mahadevan, R. Ellsworth, L. Cooke, D. Bearss, B. Stea, The c-Met receptor tyrosine kinase inhibitor MP470 radiosensitizes glioblastoma cells, Radiat. Oncol. (London, England) 4 (2009) 69.

[85] H. Zhao, K.R. Luoto, A.X. Meng, R.G. Bristow, The receptor tyrosine kinase inhibitor amuvatinib (MP470) sensitizes tumor cells to radio- and chemo-therapies in part by inhibiting homologous recombination, Radiother. Oncol. 101 (1) (2011) 59-65.

[86] P. Taverna, L. Huang, G. Choy, M. Azab, 171 Amuvatinib (MP-470), a multi-targeted tyrosine kinase inhibitor and DNA repair suppressor, synergizes with etoposide (VP-16) in small cell lung cancer (SCLC) cell lines and xenografts, Eur. J. Cancer Suppl. 8 (7) (2010) 59.

[87] M. Mita, M. Gordon, L. Rosen, N. Kapoor, G. Choy, S. Redkar, P. Taverna, A. Oganesian, A. Sahai, M. Azab, R. Bristow, A.W. Tolcher, Phase 1B study of amuvatinib in combination with five standard cancer therapies in adults with advanced solid tumors, Cancer Chemother. Pharmacol. 74 (1) (2014) 195-204.

[88] L. Byers, L. Horn, J. Gandhi, G. Kloecker, T.K. Owonikoko, S. Waqar, M.J. Krzakowski, G. Choy, N. Cecchettini, P. Taverna, A. Sahai, M. Noursalehi, M. Azab, D.R. Camidge, Abstract 2095: A phase 2 study of Amuvatinib (MP-470), the first RAD51 inhibitor in combination with platinum-etoposide (PE) in refractory or relapsed small cell lung cancer (ESCAPE), Cancer Res. 73 (8 Supplement) (2013) 2095.

[89] Edward A. Nam, D. Cortez, ATR signalling: more than meeting at the fork, Biochem. J. 436 (3) (2011) 527-536.

[90] L. Ding, G. Getz, D.A. Wheeler, E.R. Mardis, M.D. McLellan, K. Cibulskis, C. Sougnez, H. Greulich, D.M. Muzny, M.B. Morgan, L. Fulton, R.S. Fulton, Q. Zhang, M.C. Wendl, M.S. Lawrence, D.E. Larson, K. Chen, D.J. Dooling, A. Sabo, A.C. Hawes, H. Shen, S.N. Jhangiani, L.R. Lewis, O. Hall, Y. Zhu, T. Mathew, Y. Ren, J. Yao, S.E. Scherer, K. Clerc, G.A. Metcalf, B. Ng, A. Milosavljevic, M.L. Gonzalez Garay, J.R. Osborne, R. Meyer, X. Shi, Y. Tang, D.C. Koboldt, L. Lin, R. Abbott, T.L. Miner, C. Pohl, G. Fewell, C. Haipek, H. Schmidt, B.H. Dunford-Shore, A. Kraja, S.D. Crosby, C.S. Sawyer, T. Vickery, S. Sander, J. Robinson, W. Winckler, J. Baldwin, L.R. Chirieac, A. Dutt, T. Fennell, M. Hanna, B.E. Johnson, R.C. Onofrio, R.K. Thomas, G. Tonon, B.A. Weir, X. Zhao, L. Ziaugra, M.C. Zody, T. Giordano, M.B. Orringer, J.A. Roth, M.R. Spitz, I.I. Wistuba, B. Ozenberger, P.J. Good, A.C. Chang, D.G. Beer, M.A. Watson, M. Ladanyi, S. Broderick, A. Yoshizawa, W.D. Travis, W. Pao, M.A. Province, G.M. Weinstock, H.E. Varmus, S.B. Gabriel, E.S. Lander, R.A. Gibbs, M. Meyerson, R.K. Wilson, Somatic mutations affect key pathways in lung adenocarcinoma, Nature 455 (7216) (2008) 1069-1075.

[91] C. Greenman, P. Stephens, R. Smith, G.L. Dalgliesh, C. Hunter, G. Bignell, H. Davies, J. Teague, A. Butler, C. Stevens, S. Edkins, S. O'Meara, I. Vastrik, E.E. Schmidt, T. Avis, S. Barthorpe, G. Bhamra, G. Buck, B. Choudhury, J. Clements, J. Cole, E. Dicks, S. Forbes, K. Gray, K. Halliday, R. Harrison, K. Hills, J. Hinton, A. Jenkinson, D. Jones, A. Menzies, T. Mironenko, J. Perry, K. Raine, D. Richardson, R. Shepherd, A. Small, C. Tofts, J. Varian, T. Webb, S. West, S. Widaa, A. Yates, D.P. Cahill, D.N. Louis, P. Goldstraw, A.G. Nicholson, F. Brasseur, L. Looijenga, B.L. Weber, Y.E. Chiew, A. DeFazio, M.F. Greaves, A.R. Green, P. Campbell, E. Birney, D.F. Easton, G. Chenevix-Trench, M.H. Tan, S.K. Khoo, B.T. Teh, S.T. Yuen, S.Y. Leung, R. Wooster, P.A. Futreal, M.R. Stratton, Patterns of somatic mutation in human cancer genomes, Nature 446 (7132) (2007) 153-158.

[92] H. Jiang, H.C. Reinhardt, J. Bartkova, J. Tommiska, C. Blomqvist, H. Nevanlinna, J. Bartek, M.B. Yaffe, M.T. Hemann, The combined status of ATM and p53 link tumor development with therapeutic response, Genes Dev. 23 (16) (2009) 1895-1909.

[93] P.M. Reaper, M.R. Griffiths, J.M. Long, J.-D. Charrier, S. MacCormick, P.A. Charlton, J.M.C. Golec, J.R. Pollard, Selective killing of ATM- or p53-deficient cancer cells through inhibition of ATR, Nat. Chem. Biol. 7 (7) (2011) 428-430.

[94] A.B. Hall, D. Newsome, Y. Wang, D.M. Boucher, B. Eustace, Y. Gu, B. Hare, M.A. Johnson, S. Milton, C.E. Murphy, D. Takemoto, C. Tolman, M. Wood, P. Charlton, J.D. Charrier, B. Furey, J. Golec, P.M. Reaper, J.R. Pollard, Potentiation of tumor responses to DNA damaging therapy by the selective ATR inhibitor VX970, Oncotarget 5 (14) (2014) 5674-5685.

[95] R. Josse, S.E. Martin, R. Guha, P. Ormanoglu, T.D. Pfister, P.M. Reaper, C.S. Barnes, J. Jones, P. Charlton, J.R. Pollard, J. Morris, J.H. Doroshow, Y. Pommier, ATR inhibitors VE-821 and VX-970 sensitize cancer cells to topoisomerase i inhibitors by disabling DNA replication initiation and fork elongation responses, Cancer Res. 74 (23) (2014) 6968-6979.

[96] M.E. Olmedo Garcia, M. Forster, E. Calvo, V. Moreno, M.P. Lopez Criado, J.A. Lopez-Vilarino de Ramos, C. Kahatt, P. Lardelli, X.E. Luepke-Estefan, A. SotoMatos, 1529PDActivity of lurbinectedin as single agent and in combination in patients with advanced small cell lung cancer (SCLC), Ann. Oncol. 28 (suppl_5) (2017) mdx386.003-mdx386.003.

[97] A. George, S. Kaye, S. Banerjee, Delivering widespread BRCA testing and PARP inhibition to patients with ovarian cancer, Nat. Rev. Clin. Oncol. 14 (5) (2016) 284-296.

[98] D. Lim, J. Ngeow, Evaluation of the methods to identify patients who may benefit from PARP inhibitor use, Endocr. Relat. Cancer 23 (6) (2016) R267-85.

[99] L.A. Byers, L. Krug, S. Waqar, A. Dowlati, C. Hann, A. Chiappori, T. Owonikoko, K. Woo, Y. Bensman, B. Hurtado, R. Cardnell, L. Diao, Y. Fan, J. Fujimoto, J. Rodriguez-Canales, L. Long, E. Sulman, I. Wistuba, J. Wang, W. Travis, A. Chen, C. Rudin, M. Kris, M. Fleisher, J. Heymach, M.C. Pietanza, MA11.07 improved small cell lung cancer (SCLC) response rates with veliparib and temozolomide: results from a phase II trial, J. Thorac. Oncol. 12 (1) (2016) S406-S407. 